\title{
Strategi Guru PAUD dalam Mengembangkan Kecerdasan Interpersonal Anak Usia Dini di Saat Belajar dari Rumah
}

\author{
Mubiar Agustin1, Dinar Nur Inten ${ }^{2}$, Andalusia Neneng Permatasari ${ }^{3 凶}$, Dewi Mulyani ${ }^{4}$ \\ Pendidikan Guru Pendidikan Anak Usia Dini, Universitas Pendidikan Indonesia(1) \\ Pendidikan Guru Pendidikan Anak Usia Dini, Universitas Islam Bandung(2,4) \\ Ilmu Komunikasi, Universitas Islam Bandung(3)
}

DOI: $10.31004 /$ obsesi.v5i2.1055

\begin{abstract}
Abstrak
Mewabahnya pandemi covid 19 secara masif yang menimpa hampir seluruh negara di dunia berdampak pada semua sendi kehidupan termasuk pendidikan. Aktivitas belajar mengajar pada Pendidikan Anak Usia Dini (PAUD) akhirnya menuntut anak untuk belajar dari rumah (BDR). Kondisi ini menimbulkan hambatan dalam pengembangan kecerdasan interpersonal anak karena tidak adanya interaksi langsung dengan teman-teman sebayanya. Tujuan penelitian ini adalah berupaya mengungkap strategi guru PAUD dalam mengembangkan kecerdasan interpersonal anak usia dini saat belajar dari rumah. Pendekatan yang digunakan dalam penelitian adalah kuantiaitif dengan metode survey. Data penelitian diperoleh secara online menggunakan media google form. Jumlah responden sebanyak 251 guru PAUD yang tersebar di wilayah Jawa Barat. Instrumen yang digunakan dalam penelitian ini adalah angket dengan skala yang digunakan adalah skala likert. Hasil penelitian menunjukkan bahwa strategi guru yang di butuhkan untuk mengembangkan kecerdasan interpersonal anak usia dini yaitu strategi yang sesuai perkembangan anak, pembelajaran mudah dilakukan oleh orang tua di rumah, bermakna dan menyenangkan.
\end{abstract}

Kata Kunci: kecerdasan interpersonal; anak usia dini; bdr (belajar dari rumah)

\footnotetext{
Abstract

The massive outbreak of the Covid 19 pandemic hit almost all countries in the world. It has impact on all aspect of life, including education. Teaching and learning activities in early childhood education (PAUD) ultimately require children to learn from home (BDR). This condition creates obstacles in the development of children's interpersonal intelligence because there is no direct interaction with their peers. The purpose of this research is to try to reveal the strategies of early childhood teachers in developing interpersonal intelligence in early childhood when learning from home. The approach used in this research is quantitative survey method. The research data was obtained online using google form media. The number of respondent was 251 PAUD teachers spread accros West Java. The instrument used in this study was a questionnaire with the scale used was the likert scale. The result show that the teacher strategies needed to develop interpersonal intelligence, such as children's development, learning is easy for parents to do at home, meaningful, and fun.

Keywords: interpersonal intelligence; early childhood; bdr (learning from home)

Copyright (c) 2021 Mubiar Agustin, Dinar Nur Inten, Andalusia Neneng Permatasari, Dewi Mulyani

$\triangle$ Corresponding author:

Email Address: mubiar@upi.edu (Bandung, Indonesia)

Received 18 January 2021, Accepted 31 January 2021, Published 10 February 2021
} 


\section{PENDAHULUAN}

Salah satu potensi perkembangan yang ada pada diri anak usia dini adalah potensi kecerdasan majemuk. Potensi kecerdasan majemuk yang ada pada diri anak perlu dikembangkan sejak dini dengan menggunakan ragam kegiatan yang menyenangkan dan bermakna bagi anak (Muslihuddin \& Agustin, 2017). Salah satu kecerdasan majemuk yang perlu dikembangkan adalah kecerdasan interpersonal. Kecerdasan interpersonal anak usia dini berkaitan dengan kapasitas untuk memahami maksud, motivasi dan keinginan orang lain (Musfirah, 2004). Kecerdasan ini akan membantu anak di masa yang akan datang orang untuk bekerja lebih efektif dengan yang lain. Para pendidik, pramuniaga, pemuka agama, pemimpin politik, penyuluh semua memerlukan pengembangan kecerdasan interpersonal (Armstrong, 2003). Artinya, inti dari kecerdasan interpersonal adalah kemampuan anak dalam mengembangkan jalinan interaksi dengan orang lain secara positif. Ini sejalan dengan asumsi bahwa salah satu pilar pendidikan anak usia dini adalah pengembangan kemampuan sosial dan emosi (Nurihsan \& Agustin, 2011). Salah satu kecerdasan yang penting dalam aspek perkembangan sosial anak adalah kecerdasan interpersonal (Sahidun, 2018).

Akan tetapi faktanya, pada masa pandemi ini tidak sedikit anak yang mengalami kendala dalam melakukan interaksi dengan teman sebayanya karena kekhawatiran terinfeksi covid 19. Padahal dalam beberapa penelitian ditemukan fakta tentang urgensi interaksi sosial dalam kehidupan anak usia dini. Ada sebuah penelitian yang menunjukkan bahwa perkembangan sosial dan emosi anak usia dini memegang peranan penting dalam kehidupan anak (Syaodih, 1999). Perkembangan sosial emosi banyak membantu anak dalam menjalin relasi sosial, kegiatan bermain dan juga bersosialisasi (Tatminingsih, 2019). Perkembangan sosial pada anak usia dini merupakan perolehan kemampuan berprilaku yang membantu anak untuk menyesesuaikan diri dengan tuntutan sosial yang ada di lingkunganya (Hurlock, 2001). Adapun dalam konteks urgensi kemampuan bersosialisasi, sosialisasi adalah kemampuan bertingkah laku sesuai dengan norma, nilai atau harapan sosial (Hurlock, 2001). Dalam hal ini, anak mulai belajar mengembangkan kemampuan sosial dalam bentuk bertingkah laku sesuai dengan harapan lingkungan, belajar memainkan peran sosial dalam aktivitas dengan teman sebayanya, dan tidak lupa anak juga mengembangkan sikap/tingkah laku sosial terhadap individu lain dan aktivitas sosial yang berada dimasyarakat.

Terkait dengan urgensi pengembangan kecerdasan interperonal anak usia dini telah banyak penelitian yang menyatakan kecerdasan interpersonal memegang peranan penting dalam rentang perkembangan anak usia dini (Sary, 2018). Kecerdasan ini perlu mendapatkan stimulasi yang tepat sehingga kecerdasan tersebut dapat tumbuh dan berkembang secara optimal (Sari, 2018). Ilustrasi pentingnya pengembangan kecerdasan interpersonal dalam spektrum perkembangan anak sebagaimana ikan membutuhkan air dan juga butuhnya tanaman dengan tanah yang subur (Y Pahrul, 2019). Terdapat berbagai kegiatan yang dapat dilakukan untuk mengembangkan kecerdasan ini antara lain kegiatan menggambar, berkebun, berkemah, outbond, dan juga bercerita. Kecerdasan interpersonal pada anak itu sendiri merupakan kemampuan mempersepsikan dan membedakan dalam modus, maksud tertentu, motivasi dan perasaan dari orang lain (Lazear, 1999). Di dalam kecerdasan ini termasuk kepekaan ekspresi muka, suara dan gerak-gerik. Memiliki kemampuan untuk membedakan hal-hal dari banyak jenis tanda-tanda interpersonal. Memiliki kemampuan untuk bereaksi secara efektif terhadap tanda-tanda demikian secara pragmatik. merupakan kemampuan untuk memahami dan berkomunikasi dengan orang lain, mampu membedakan suasana hati, temperamen, motivasi dan keterampilan-keterampilan dalam memahami orang lain. Termasuk juga kemampuan untuk membentuk dan memelihara hubungan dengan orang lain serta memahami berbagai peran dalam kelompok.

Kecerdasan ini umumnya ditunjukkan oleh orang-orang yang berkecimpung di bidang politik, agama, guru, orang tua, terapis maupun konselor Ciri-ciri yang menonjol dari kecerdasan ini adalah cenderung mampu berempati pada teman-temannya, pandai mengorganisasi teman-temannya untuk melakukan tugas, cenderung peka dalam mengenali 
dan membaca pikiran orang lain, cenderung memiliki banyak teman dan mampu menjalin hubungan dengan teman-temannya, cenderung mudah memahami perasaan orang lain, lebih sering menjadi pemimpin di antara teman-temannya, dan memiliki perhatian yang besar kepada teman-temannya sehingga acapkali mengetahui berita-berita di seputar mereka.

Pada kondisi anak sedang belajar dari rumah karena pandemi Covid 19 tentunya anak menjadi terbatas untuk dapat berinteraksi dengan teman sebayanya dan juga gurunya. Padahal dua kelompok ini merupakan individu yang besar pengaruhnya dalam membantu anak mengembangkan kecerdasan interpersonal. Kedua kelompok ini juga berperan dalam membantu menciptakan iklim pembelajaran yang kondusif dan positif. Pembelajaran positif itu sendiri merupakan realisasi dari aksi guru untuk unjuk profesionalisme dengan berbasis kepada pengalaman dan praktek yang mereka lakukan dan miliki, jika ini terkendala maka akan sulit diperoleh peningkatan mutu pembelajaran apalagi jika unsur-unsur interaksi pedagogik dalam pembelajaran ikut memudar terlebih jika guru sendiri mengalami banyak kendala khususnya saat pandemi Covid 19 (Agustin et al., 2020).

Tentunya guru PAUD perlu melakukan suatu strategi yang tepat, feleksibel dan berorientasi kepada pengembangan potensi anak khususnya dalam mengembangkan kecerdasan interpersonal anak pada saat belajar dari rumah. Alasan ini sangat mendasar mengingat salah satu ciri perkembangan itu sendiri adalah tidak dapat terulang maka jika pengembangan kecerdasan interpersonal pada anak saat pandemi ini terlewat begitu saja maka dapat diprediksi anak akan mengalami kendala perkembangan dikemudian hari. Maka berdasarkan beberapa alasan yang dipaparkan di atas, penelitian ini memfokuskan kajian pada strategi guru PAUD dalam mengembangkan kecerdasan interpersonal anak usia dini saat belajar dari rumah. Kajian ini berbeda dengan beberapa kajian sebelumnya karena penelitian ini dilakukan dalam konteks pandemi covid. Adapun tujuan penelitian ini adalah untuk mengetahui strategi yang tepat dalam mengembangkan kecerdasan interpersonal anak usia dini di masa pandemi covid.

\section{METODOLOGI}

Metode yang digunakan dalam penelitian ini adalah survei dan pendekatannya kuantitatif. Metode survei diterapkan dalam penelitian ini dengan mendeskripsikan secara kuantitatif kecenderungan-kecenderungan perilaku dari suatu populasi dengan meneliti sampel populasi tersebut (Borg \& Gall, 2003). Perilaku-perilaku yang dimaksud dalam penelitian ini adalah strategi yang dilakukan oleh guru-guru PAUD dalam mengembangkan kecerdasan interpersonal anak usia dini pada saat belajar dari rumah (BDR). Pengembangan instrumen dilakukan melalui merujuk kepada teori yang relevan terkait dengan kecerdasan majemuk khususnya kecerdasan interpersonal yaitu yang dikembangkan oleh Lazear, D (1999) yang mencakup makna dan indikator dengan ditambahkan modifikasi oleh peneliti, kemudian instrumen ditimbang oleh ahli sebanyak 3 orang yang berlatar belakang akademisi dan praktisi dengan menggunakan pernyataan yang dinyatakan sesuai dan menghilangkan pernyataan yang dinyatakan tidak sesuai. Ini dilakukan sebagai upaya melakukan validasi secara internal. Setelah itu, instrumen langsung digunakan untuk mengambil data dari lapangan dan hasilnya dianalisis.

Data dalam penelitian ini diperoleh secara online menggunakan media google form. Dalam penelitian ini jumlah responden sebanyak 251 orang guru PAUD yang terdiri dari 170 guru perempuan dan 81 guru laki-laki. yang berada di wilayah Jawa Barat. Instrumen yang digunakan dalam penelitian ini adalah angket tentang strategi guru PAUD dalam mengembangkan kecerdasan interpersonal anak usia dini saat belajar dari rumah. Gambaran desain penelitian dapat dilihat pada gambar 1. 


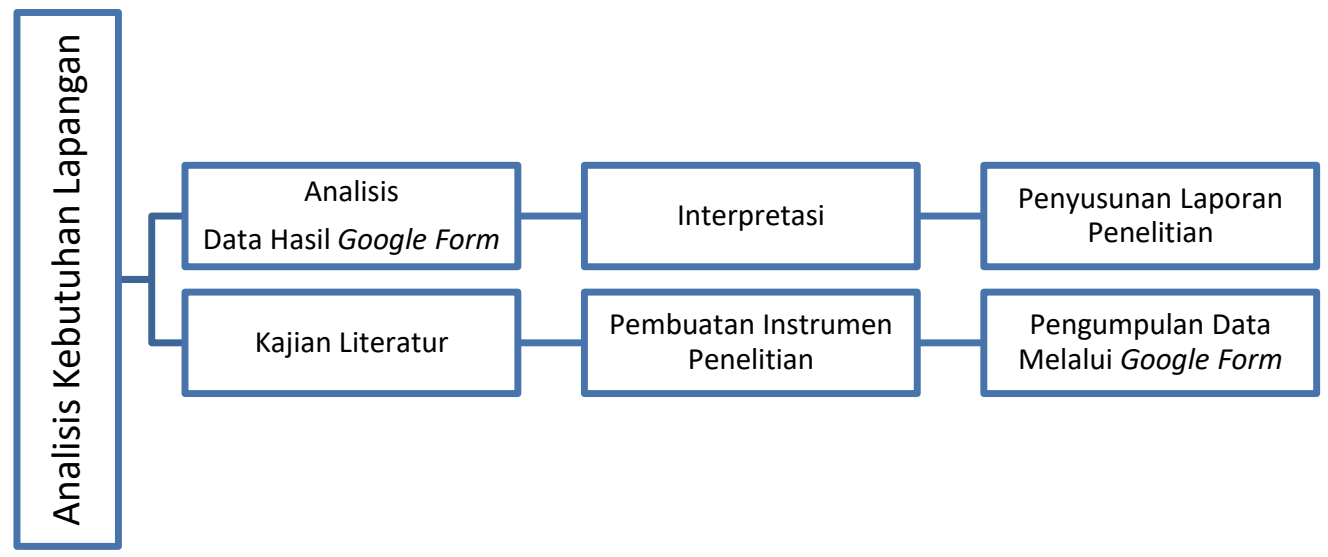

Gambar 1. Desain Penelitian

Instrument terdiri dari 7 indikator dengan 31 pernyataan, yaitu (1) indikator Urgensi Pengembangan (dengan pernyataan nomer 1 dan 2), (2) indikator Tokoh Penting (dengan pernyataan nomer 3-6), (3) indikator Media Belajar (dengan pernyataan nomer 7-14), (4) indikator Waktu Belajar (dengan pernyataan nomer 15-18); (5) indikator Metode, teknik,strategi dan pendekatan (dengan pernyataan nomer 19-22); (6) indikator Materi Kegiatan (dengan pernyataan nomer 23-26); dan (7) indikator Aturan Berkegiatan (dengan pernyataan nomer 27-31). Pengolahan data menggunakan sistem docs.google.com. Dokumen yang secara langsung menghasilkan deskripsi data berdasarkan pernyataan-pernyataan yang dijawab oleh responden.

\section{HASIL DAN PEMBAHASAN}

Hasil penelitian terkait dengan strategi guru PAUD dalam mengembangkan kecerdasan interpersonal anak usia dini saat belajar dari rumah diuraikan secara perindikator pada tabel 1 .

Tabel 1. Indikator Urgensi Pengembangan

\begin{tabular}{lllllll}
\hline NO & Pernyataan & $\begin{array}{l}\text { Sangat } \\
\text { Penting }\end{array}$ & Penting & $\begin{array}{l}\text { Kurang } \\
\text { Penting }\end{array}$ & $\begin{array}{l}\text { Tidak } \\
\text { Penting }\end{array}$ & $\begin{array}{l}\text { Sangat } \\
\text { Tidak } \\
\text { Penting }\end{array}$ \\
\hline 1 & $\begin{array}{l}\text { Pengembangan kecerdasan } \\
\text { interpersonal anak usia dini saat belajar } \\
\text { dari rumah }\end{array}$ & $68,9 \%$ & $30,7 \%$ & & & \\
2 & $\begin{array}{l}\text { Pengembangan kecerdasan } \\
\text { interpersonal bagi anak dilakukan saat } \\
\text { masa pandemi. }\end{array}$ & $57,4 \%$ & $41.4 \%$ & $0,8 \%$ & & \\
\hline
\end{tabular}

\section{Sumber data hasil survei}

Berdasarkan hasil penelitian terlihat jelas bahwa pengembangan kecerdasan interpersonal pada rentang perkembangan anak usia dini memegang peranan yang sangat penting. Hal ini sangat wajar sebab salah satu pilar dalam pendidikan anak usia dini itu sendiri adalah membekali anak dengan berbagai keterampilan supaya anak mampu berinteraksi dengan teman sebayanya secara positif dan juga anak memiliki kendali emosi yang baik khususnya dalam mengeskpresikan diri baik secara internal ataupun eksternal dan kemampuan tersebut terakomodir dalam kecerdasan interpersonal (Beaty, 2013). Kecerdasan interpersonal merupakan bagian dari kecerdasan majemuk (Brown, 2010). Kecerdasan majemuk memiliki karakteristik sebagai berikut semua intelegensi itu berbeda-beda, tetapi semuanya sederajat. Dalam pengertian ini, tidak ada kecerdasan yang lebih baik atau lebih penting dari kecerdasan yang lain, semua kecerdasan dimiliki manusia dalam kadar yang 
tidak persis sama. Semua kecerdasan dapat dieksplorasi, ditumbuhkan dan dikembangkan secara optimal, terdapat banyak indikator kecerdasan dalam tiap-tiap kecerdasan.

Hasil penelitian terkait dengan strategi guru PAUD dalam mengembangkan kecerdasan interpersonal anak usia dini saat belajar dari rumah dengan indikator tokoh penting pada kegiatan pembelajaran pada tabel 2 .

Peran orang tua sebagai tokoh penting dalam tumbuh kembang dan pengenalan fondasi dasar kehidupan bagi anak tak kan pernah tergantikan. Begitu pula dalam pengenalan dan pembelajaran untuk mengembangkan kecerdasan interpersonal anak, orang tua memiliki peranan penting dalam memberikan contoh dan keteladanan yang baik sehingga anak mampu berkomunikasi dengan sopan, santun dalam kehidupan sehari-hari. (Inten, 2017), orang tua merupakan teladan dan figur utama dalam kehidupan anak orang tualah yang mengajarkan cara hidup yang baik dan cara agar anak dapat mengoptimalisasikan prestasi dan kemampuan yang dimilikinya. Apalagi pada saat ini dimana kebanyakan orang tua melakukan pekerjaannya dari rumah maka orang tua dapat mengoptimalkan perannya sebagai panutan yang baik. (Permatasari et al., 2021) keintiman dan kelekatan dalam suatu keluarga dapat terbangun jika orang tua dapat memerankan perannya dengan baik dan anak dapat mengekpresikan perasaan dan menyampaikan gagasan yang dimilikinya dengan nyaman dan aman.

Tabel 2 Tokoh Penting

\begin{tabular}{|c|c|c|c|c|c|c|}
\hline No & Pernyataan & $\begin{array}{l}\text { Sangat } \\
\text { Penting }\end{array}$ & Penting & $\begin{array}{l}\text { Kurang } \\
\text { Penting }\end{array}$ & $\begin{array}{l}\text { Tidak } \\
\text { Penting }\end{array}$ & $\begin{array}{l}\text { Sangat } \\
\text { Tidak } \\
\text { Penting }\end{array}$ \\
\hline 3 & $\begin{array}{l}\text { Orang tua memiliki peranan dalam } \\
\text { mengembangkan kecerdasan } \\
\text { interpersonal anak usia dini saat belajar } \\
\text { dari rumah. }\end{array}$ & $71,4 \%$ & $28,6 \%$ & & & \\
\hline 4 & $\begin{array}{l}\text { Guru berperan strategis dalam } \\
\text { mengembangkan kecerdasan } \\
\text { interpersonal saat anak belajar dari } \\
\text { rumah. }\end{array}$ & $54 \%$ & $44,8 \%$ & $1,2 \%$ & & \\
\hline 5 & $\begin{array}{l}\text { Kolaborasi Orang tua dengan guru } \\
\text { dalam mengembangkan kecerdasan } \\
\text { interpersonal anak usia dini. }\end{array}$ & $80,2 \%$ & $19,4 \%$ & & & \\
\hline 6 & $\begin{array}{l}\text { Pelibatan anggota keluarga non orang } \\
\text { tua dalam mengembangkan kecerdasan } \\
\text { interpersonal anak usia dini saat belajar } \\
\text { dari rumah }\end{array}$ & $33,1 \%$ & $54,9 \%$ & $6,8 \%$ & $0,8 \%$ & \\
\hline
\end{tabular}

Hasil penelitian terkait dengan strategi guru PAUD dalam mengembangkan kecerdasan interpersonal anak usia dini saat belajar dari rumah dengan indikator media pembelajaran pada tabel 3 .

Dalam pengajaran anak usia dini maka tidak dapat terlepas dari yang namanya media. Dengan media berbagai hal yang disampaikan pada anak akan dapat dengan mudah dipahami, dan anakpun akan merasakah kesenangan dan tertarik mengikuti pembelajaran oleh karena itu pada pertanyaan terkait media pembelajaran untuk mengembangakan kecerdasan interpersonal anak 50\% rata-arat respon menjawab bahwa media sangatlah penting. Pada saat pandemi media yang dibutuhkan adalah media yang mudah di dapatkan di sekitar tempat tinggal anak, baik barang bekas, bahan alam ataupun media gambar sederhana. (Yolanda Pahrul et al., 2019), menyatakan bahawa menggambar bisa menjadi salah satu kegiatan yang digunakan untuk mengembangkan kecerdasan interpersonal anak usia dini karena melalui menggambar anak dapat mengekspresikan perasaan dan emosinya secara 
bebas, dan menggambar dengan berbagai media yang ada di sekitar anak sangatlah menyenangkan dan dapat membangun kreativitas anak. Hasil penelitian terkait dengan strategi guru PAUD dalam mengembangkan kecerdasan interpersonal anak usia dini saat belajar dari rumah dengan waktu belajar, terlihat pada tabel 4 .

Dalam melakukan aktivitas untuk pengembangan kecerdasan anak secara optimal di butuhkan waktu khusus dimana anak dan orang tua dapat terlibat secara langsung dan merasakan kenyamana dan kesenangan, hal ini terlihat dari 56,7\% respon menjawab bahwasanya diperlukan waktu khusus dalam pengembangan kecerdasan interpersonal anak. Dalam satu kegiatan seorang individu kegiatan mungkin memerlukan lebih dari satu kecerdasan, dan satu kecerdasan dapat digunakan dalam berbagai bidang, semua jenis kecerdasan tersebut ditemukan di seluruh/semua lintas kebudayaan di seluruh dunia dan kelompok usia; dan saat seseorang dewasa, kecerdasan diekspresikan melalui rentang pencapaian profesi dan hobi. Kecerdasan logika-matematika yang dimulai sebagai kemampuan pola pada masa balita dan berkembang menjadi penguasaan simbolik pada masa anak-anak, misalnya akhirnya mencapai kematangan ekspresi dalam wujud profesi sebagai ahli matematika, akuntan dan itu sendiri adalah menghargai keunikan setiap individu, berbagai variasi cara belajar, mewujudkan sejumlah model untuk menilai mereka dan cara yang hampir tak terbatas untuk mengaktualisasikan diri di dunia ini (Lwin, 2003).

Tabel 3 Media Belajar

\begin{tabular}{|c|c|c|c|c|c|c|}
\hline No & Pernyataan & $\begin{array}{l}\text { Sangat } \\
\text { Penting }\end{array}$ & Penting & $\begin{array}{l}\text { Kurang } \\
\text { Penting }\end{array}$ & $\begin{array}{l}\text { Tidak } \\
\text { Penting }\end{array}$ & $\begin{array}{l}\text { Sangat } \\
\text { Tidak } \\
\text { Penting }\end{array}$ \\
\hline 7 & $\begin{array}{l}\text { Perlu media yang tepat untuk } \\
\text { mengembangkan kecerdasan interpersonal } \\
\text { anak usia dini saat belajar dari rumah. }\end{array}$ & $54,2 \%$ & $42,2 \%$ & $3,6 \%$ & & \\
\hline 8 & $\begin{array}{l}\text { Orang tua dan guru perlu membantu } \\
\text { memilih media yang tepat untuk } \\
\text { pengembangan kecerdasan interpersonal } \\
\text { anak saat belajar dari rumah. }\end{array}$ & $62.3 \%$ & $36,5 \%$ & $1,2 \%$ & & \\
\hline 9 & $\begin{array}{l}\text { Media belajar untuk pengembangan } \\
\text { kecerdasan interpersonal anak usia dini saat } \\
\text { belajar dari rumah bagi anak bersifat mudah } \\
\text { didapat. }\end{array}$ & $50,6 \%$ & $48,6 \%$ & $0,8 \%$ & & \\
\hline 10 & $\begin{array}{l}\text { Media belajar untuk pengembangan } \\
\text { kecerdasan interpersonal anak usia dini saat } \\
\text { belajar dari rumah bagi anak mudah } \\
\text { digunakan. }\end{array}$ & $55,2 \%$ & $44 \%$ & $0.8 \%$ & & \\
\hline 11 & $\begin{array}{l}\text { Media belajar untuk pengembangan } \\
\text { kecerdasan interpersonal anak usia dini saat } \\
\text { belajar dari rumah bagi anak bersifat ramah } \\
\text { lingkungan. }\end{array}$ & $62,3 \%$ & $37,3 \%$ & $0,4 \%$ & & \\
\hline 12 & $\begin{array}{l}\text { Media belajar untuk pengembangan } \\
\text { kecerdasan interpersonal anak usia dini saat } \\
\text { belajar dari rumah bagi anak harganya } \\
\text { murah. }\end{array}$ & $45 \%$ & $49,4 \%$ & $4 \%$ & & \\
\hline 13 & $\begin{array}{l}\text { Media belajar untuk pengembangan } \\
\text { kecerdasan interpersonal anak usia dini saat } \\
\text { belajar dari rumah dapat digunakan secara } \\
\text { berulang-ulang. }\end{array}$ & $43,6 \%$ & $52 \%$ & $4 \%$ & & \\
\hline 14 & $\begin{array}{l}\text { Media belajar untuk pengembangan } \\
\text { kecerdasan interpersonal anak usia dini saat } \\
\text { belajar dari rumah dapat digunakan secara } \\
\text { bersama-sama dengan melibatkan orang tua }\end{array}$ & $55 \%$ & $43,8 \%$ & $1,2 \%$ & $0,8 \%$ & $0,8 \%$ \\
\hline
\end{tabular}

Sumber data hasil survei 
Dalam pengembangan kecerdasan interpersonal ada hal-hal yang harus dapat dicapai anak pada usia tertentu agar ketika anak tersebut berajak meninggalkan masa kanakkanannya kecerdasan interpersonal sebagai dasar untuk bekal berkomunikasi dengan msayarakat telah dimilikinya. Beberapa hal terkait kecerdasan interpersonal anak yang harus dikembangkan berdasarkan penelitian (Qowiyah, 2020), anak masih suka menganggu temannya, anak masih sering bermain hanya dengan teman dekatnya, anak belum mampu bekerjasama dengan baik serta anak masih belum bisa menjadi pendengar yang baik.

Lebih lanjut, menjelaskan bahwa kecerdasan interpersonal merupakan bentuk yang paling penting dalam kecerdasan manusia, karena dengan kecerdasan itu ia mampu memelihara hubungan dengan manusia secara efektif (Behjat, 2012). Mereka mampu mempertimbangkan konsekuensi dari perilaku mereka sendiri serta mengantisipasi perilaku orang lain. Keberhasilan dalam kehidupan seseorang seringkali sangat tergantung pada kecerdasan interpersonalnya. Oleh karena itu, kecerdasan interpersonal harus dikembangkan (Beceren, 2010).

Tabel 4. Waktu Belajar

\begin{tabular}{|c|c|c|c|c|c|c|}
\hline No & Pernyataan & $\begin{array}{l}\text { Sangat } \\
\text { Penting }\end{array}$ & Penting & $\begin{array}{l}\text { Kurang } \\
\text { Penting }\end{array}$ & $\begin{array}{l}\text { Tidak } \\
\text { Penting }\end{array}$ & $\begin{array}{l}\text { Sangat } \\
\text { Tidak } \\
\text { Penting }\end{array}$ \\
\hline 15 & $\begin{array}{l}\text { Waktu kegiatan untuk mengembangkan } \\
\text { kecerdasan interpersonal saat anak } \\
\text { belajar dari rumah bersifat fleksibel. }\end{array}$ & $45,6 \%$ & $53,2 \%$ & $0,8 \%$ & & \\
\hline 16 & $\begin{array}{l}\text { Memilih waktu yang tepat untuk } \\
\text { mengembangkan kecerdasan } \\
\text { interpseronal anak usia dini saat belajar } \\
\text { dari rumah. }\end{array}$ & $49,8 \%$ & $47,4 \%$ & $2,4 \%$ & & \\
\hline 17 & $\begin{array}{l}\text { Anak diberikan kebebasan untuk } \\
\text { menentukan waktu berkegiatannya saat } \\
\text { belajar di rumah termasuk kegiatan } \\
\text { pengembangan kecerdasan interpersonal. }\end{array}$ & $41,7 \%$ & $50,4 \%$ & $6,7 \%$ & $1,2 \%$ & \\
\hline 18 & $\begin{array}{l}\text { Menentukan waktu yang tepat agar anak } \\
\text { dan orang tua dapat ikut belajar dan } \\
\text { bermain bersama-sama }\end{array}$ & $56,7 \%$ & $41,7 \%$ & $0,8 \%$ & $0,4 \%$ & \\
\hline
\end{tabular}

Terkait hasil penelitian strategi guru PAUD dalam mengembangkan kecerdasan interpersonal anak usia dini saat belajar dari rumah dengan indikator metode, teknik, strategi dan pendekatan tertuang pada tabel 5.

Metode, teknik, strategi dan pendekatan tidak dapat terlepaskan dalam sebuah pembelajaran anak usia dini. Karena melalui empat hal tersebut pembelajaran dapat disamapaiakn dan dikemas semenarik mungkin sehingga anak merasa betah, tertarik dan senang mengikuti aktivitas pembelajaran yang berlangsung. Oleh karena itu 71,3\% respon menjawab bahwa metode, teknik dan startegi serta pendekatan yang bermakna, mendidik dan menyenangkan. Berdasarkan hasil penelitian (Utami, 2010), menyatakan bahawa pendekatan dan pembelajaran yang bersifat proyek dimana anak melakukan pembelajaran bersama dan dituntut bekerjasama dengan teman lainnya dapat meningkatkan kecerdasan interpersonal anak. Penelitian lainnya (Royani, 2016), menyatakan bahwa model pembelajaran berbasis masalah dapat digunakan untuk mengembakan kecerdasan interpersonal dan membantu membangun kepercayaan diri anak untuk mengungkap ide dan gagasan dalam memecahkan masalah yang ada.

Terkait hasil penelitian strategi guru PAUD dalam mengembangkan kecerdasan interpersonal anak usia dini saat belajar dari rumah dengan indikator materi kegiatan tertuang pada tabel 6. 
Tabel 5. Metode, Teknik, Strategi, dan Pendekatan

\begin{tabular}{|c|c|c|c|c|c|c|}
\hline No & Pernyataan & $\begin{array}{l}\text { Sangat } \\
\text { Penting }\end{array}$ & Penting & $\begin{array}{l}\text { Kurang } \\
\text { Penting }\end{array}$ & $\begin{array}{l}\text { Tidak } \\
\text { Penting }\end{array}$ & $\begin{array}{l}\text { Sangat } \\
\text { Tidak } \\
\text { Penting }\end{array}$ \\
\hline 19 & $\begin{array}{l}\text { Menentukan metode, teknik, strategi, } \\
\text { dan pendekatan untuk pengembangan } \\
\text { kecerdasan interpersonal anak usia dini } \\
\text { saat belajar dari rumah }\end{array}$ & $62,3 \%$ & $36,7 \%$ & $0,8 \%$ & & \\
\hline 20 & $\begin{array}{l}\text { Memilih metode,teknik, strategi, dan } \\
\text { pendekatan untuk pengembangan } \\
\text { kecerdasan interpersonal anak yang } \\
\text { mudah diterapkan orangtua selama } \\
\text { belajar di rumah. }\end{array}$ & $63,1 \%$ & $35,3 \%$ & $1,6 \%$ & & \\
\hline 21 & $\begin{array}{l}\text { Memilih metode, strategi, dan } \\
\text { pendekatan untuk pengembangan } \\
\text { kecerdasan interperonal anak sesuai } \\
\text { dengan kebutuhan anak. }\end{array}$ & $62 \%$ & $37,6 \%$ & $0,4 \%$ & & \\
\hline 22 & $\begin{array}{l}\text { Metode, teknik, strategi, dan } \\
\text { pendekatan untuk pengembangan } \\
\text { kecerdasan interperonal anak } \\
\text { mengandung aktivitas yang } \\
\text { menyenangkan, bermakna dan } \\
\text { mendidik. }\end{array}$ & $71,3 \%$ & $28,7 \%$ & & & \\
\hline
\end{tabular}

Tabel 6. Materi Kegiatan

\begin{tabular}{|c|c|c|c|c|c|c|}
\hline No & Pernyataan & $\begin{array}{l}\text { Sangat } \\
\text { Penting }\end{array}$ & Penting & $\begin{array}{l}\text { Kurang } \\
\text { Penting }\end{array}$ & $\begin{array}{l}\text { Tidak } \\
\text { Penting }\end{array}$ & $\begin{array}{l}\text { Sangat } \\
\text { Tidak } \\
\text { Penting }\end{array}$ \\
\hline 23 & $\begin{array}{l}\text { Materi pengembangan kecerdasan } \\
\text { interpseronal anak usia dini saat belajar } \\
\text { dari rumah dimulai dari hal-hal yang } \\
\text { mudah. }\end{array}$ & $58,7 \%$ & $40,5 \%$ & $0,8 \%$ & & \\
\hline 24 & $\begin{array}{l}\text { Materi pengembangan kecerdasan } \\
\text { interpseronal anak usia dini saat belajar } \\
\text { dari rumah dibarengi dengan } \\
\text { contoh/ilustrasi yang sederhana. }\end{array}$ & $52,4 \%$ & $46,8 \%$ & $0,8 \%$ & & \\
\hline 25 & $\begin{array}{l}\text { Materi pengembangan kecerdasan } \\
\text { interpseronal anak usia dini saat belajar } \\
\text { dari rumah disampaikan secara } \\
\text { bertahap. }\end{array}$ & $52,8 \%$ & $46,8 \%$ & & & \\
\hline 26 & $\begin{array}{l}\text { Materi pengembangan kecerdasan } \\
\text { interpseronal anak usia dini saat belajar } \\
\text { dari rumah dipilih dari aktivitas yang } \\
\text { paling dekat dengan kehidupan anak } \\
\text { di rumah. }\end{array}$ & $56,3 \%$ & $42,5 \%$ & $1.2 \%$ & & \\
\hline
\end{tabular}

Dalam mengembangkan kecerdasan interpersonal anak maka materi pun dipilih sesuai kebutuhan anak dan di mulai dari hal yang mudah dipahami dan telah anak ketahui sebelumnya, hal ini terlihat dari 58,7\% responden bahwa hal tersebut sangatlah penting. Pada saat pandemi seperti ini maka materi terkait pandemi baik untuk disamapikan terhadap anak, selain agar anak melek menganai bencana yang terjadi disekitarnya anak pun dapat mengetahui langkah-langkah agar dirinya terlindung dari pandemi tersebut. Hasil penelitian menyatakan bahwa kemampuan mengkomunikasikan dengan baik berbagai hal terkait 
bencana yang terjadi dapat meredam emosi para korban mencana sehingga hal tersebut dapat membantu memulihkan kesulitan dan trauma psikologis yang idalami para korban bencana (Suhaimi et al., 2014). Materi terkait pengembangan bahasa pun dapat di pilih untuk mengembangkan kemampuan komunikasi anak yang sangat diperlukan dalam mengoptimalkan perkembangan kecerdasan interpersonal anak (Behjat, 2012).

Dan terkait hasil penelitian strategi guru PAUD dalam mengembangkan kecerdasan interpersonal anak usia dini saat belajar dari rumah dengan indikator aturan kegiatan tertuang pada tabel 7.

Tabel 7. Aturan Berkegiatan

\begin{tabular}{|c|c|c|c|c|c|c|}
\hline No & Pernyataan & $\begin{array}{l}\text { Sangat } \\
\text { Penting }\end{array}$ & Penting & $\begin{array}{l}\text { Kurang } \\
\text { Penting }\end{array}$ & $\begin{array}{l}\text { Tidak } \\
\text { Penting }\end{array}$ & $\begin{array}{l}\text { Sangat } \\
\text { Tidak } \\
\text { Penting }\end{array}$ \\
\hline 27 & $\begin{array}{l}\text { Aturan dalam kegiatan pengembangan } \\
\text { kecerdasan interpersonal anak usia dini } \\
\text { saat belajar dari rumah. }\end{array}$ & $40,9 \%$ & $55,6 \%$ & $3,6 \%$ & & \\
\hline 28 & $\begin{array}{l}\text { Kegiatan dalam pengembangan } \\
\text { kecerdasan interpseronal anak saat } \\
\text { belajar dari rumah dibuat dalam aturan } \\
\text { yang mudah dipahami. }\end{array}$ & $56,6 \%$ & $42 \%$ & $0,4 \%$ & & \\
\hline 29 & $\begin{array}{l}\text { Penggunaan aturan dalam kegiatan } \\
\text { pengembangan kecerdasan } \\
\text { interpseronal anak usia dini saat belajar } \\
\text { dari rumah perlu dibiasakan }\end{array}$ & $48,2 \%$ & $50,6 \%$ & $0,8 \%$ & & \\
\hline 30 & $\begin{array}{l}\text { Aturan dalam kegiatan pengembangan } \\
\text { kecerdasan interpseronal anak usia dini } \\
\text { saat belajar dari rumah dibuat } \\
\text { berdasarkan kesepakatan. }\end{array}$ & $46 \%$ & $48 \%$ & $5,2 \%$ & & \\
\hline 31 & $\begin{array}{l}\text { Aturan dalam kegiatan pengembangan } \\
\text { kecerdasan interpseronal anak usia dini } \\
\text { saat belajar dari rumah dibuat } \\
\text { berdasarkan perkembangan anak }\end{array}$ & $58,1 \%$ & $41,9 \%$ & $0,8 \%$ & & \\
\hline
\end{tabular}

Berdasarkan hasil penelitian terlihat jelas bahwa pengembangan kecerdasan interpersonal pada rentang perkembangan anak usia dini memegang peranan yang sangat penting. Begitu pula dengan aturan yang harus di buat atau disusun baik oleh orang tua dan guru terkait pengembangan kecerdasan interpersonal anak, hal ini terlihat dari 58,1\% jawaban responden bahwa aturan disesuaikan dengan kesepakatan dan perkembangan anak.

Kecerdasan ini menekankan kepada upaya untuk memahami dan memperkirakan perasaan, temperamen, suasana hati dan keinginan orang lain serta upaya untuk menanggapinya secara layak (Wee, 2013). Kecerdasan interpersonal anak dapat distimulasi melalui kegiatan bermain. Selama bermain anak-anak berinteraaksi dengan sebaya, guru dan juga orang tua mereka terlebih saat belajar dari rumah saat pandemi. Stimulasi tersebut dapat terjadi Karena pada saat bermain anak-anak melakukan kegiatan sebagai berikut. mempraktikan keterampilan berkomunikasi baik verbal maupun nonverbal dengan cara menegosiasikan peran, mencoba memperoleh keuntungan saat bermain atau mengapresiasi perasaan teman lain, merespon perasaan teman sepermainan di samping menunggu giliran dan berbagi materi serta pengalaman, bereksperimen dengan peran-peran di rumah, sekolah dan komunitas dengan menjalin kontak dengan kebutuhan dan kehendak orang lain, mencoba melihat sudut pandang orang lain. Begitu anak bersentuhan dengan konflik tentang ruang, waktu, materi dan aturan, mereka membangun strategi resolusi konflik secara positif. Anak-anak yang memiliki kecerdasan interpersonal cenderung mudah memahami orang lain. Mereka sering memimpin di antara teman-temannya.

Anak yang cerdas dalam interpersonal pandai mengorganiasasi teman-teman mereka dan pandai mengomunikasikan keinginan kepada orang lain. Mereka memiliki perhatian 
yang beasr kepada teman sebayanya sehingga acapkali mengetahui berita-berita yang berkembang di seputar mereka. Anak-anak yang cerdas dalam interpersonal mempunyai banyak tema (Musfirah, 2004). Mereka juga suka bersosialisasi serta senang terlibat dalam kegiatan individual ataupun kelompok. Mereka menikmati permainan-permainan yang dilakukan secara berpasang-pasangan atau berkelompok. Mereka suka memberikan apa yang dimiliki dan diketahui kepada orang lain, termasuk masalah ilmu dan informasi. Merekapun tampak menikmati ketika mengajari teman sebaya mereka tentang sesuatu, seperti membuat gambar, memilih warna, atau bahkan cara bersikap.

Terkait dengan hasil riset pada bidang otak, otak bagian depan memegang peran yang sangat penting dalam pengetahuan interpersonal (Musfirah, 2004). Kerusakan pada bagian ini dapat menyebabkan perubahan kepribadian yang besar. Kecerdasan ini bersemayam, terutama pada hemisfer kanan dan sistem limbic. Kecerdasan ini dipengaruhi oleh kedekatan kualitas atau ikatan kasih sayang selama masa kritis tiga tahun pertama. Oleh karena itu, anak yang dipisahkan dari ibunya pada masa pertumbuhan awal, mungkin akan mengalami permsaalahan yang serius. Selain itu kecerdasan interpersonal juga dipengaruhi oleh interaksi sosial dengan orang lain. Pada penelitian kali ini lebih mengkaji kepada bagaimana strategi guru dalam pengembangan kecerdasan interpersonal anak usia dini di masa pandemi covid, kajian lebih spesifik kepada konteks strategi guru. Hal ini membedakan dengan penelitian sebelumnya yang di lakukan oleh Musfiroh terkait fungsi otak dalam pengetahuan interpersonal.

\section{SIMPULAN}

Sangat penting bagi guru dalam memilih metode dan menentukan teknik, strategi, dan pendekatan untuk pengembangan kecerdasan interpersonal anak usia dini saat belajar dari rumah yang sesuai kebutuhan anak. Adapun metode, teknik, strategi, dan pendekatan haruslah mudah diaplikasikan orang tua di rumah selama BDR karena hasil penelitian ini juga menandaskan bahwa terdapat tiga kelompok penting yang dapat membantu mengembangkan kecerdasan interpersonal anak usia dini saat belajar dari rumah yaitu, guru, orang tua dan juga teman sebaya (dengan interaksi yang dilakukan sebaiknya tidak langsung). Terkait dengan pemilihan metode, teknik, strategi, dan pendekatan untuk pengembangan kecerdasan interpersonal anak usia dini saat belajar dari rumah harus mengutamakan prinsip mengandung aktivitas yang menyenangkan, bermakna dan seperti kegatan bermain, bercakap-cakap dan juga menuangkan pengalaman dalam bentuk tulisan ataupun cerita.

\section{UCAPAN TERIMA KASIH}

Penulis mengucapkan terima kasih kepada dewan editor dan redaksi Jurnal Obsesi yang telah berkenan untuk menerbitkan artikel ini. Tidak lupa penulis juga mengucapkan terima kasih kepada guru-guru PAUD yang telah bersedia menjadi responden penelitian ini.

\section{DAFTAR PUSTAKA}

Agustin, M., Puspita, R. D., Nurinten, D., \& Nafiqoh, H. (2020). Tipikal Kendala Guru PAUD dalam Mengajar Masa Pendemi Covid 19 dan Implikasinya. Jurnal Obsesi: Jurnal Pendidikan Anak Usia Dini, 2(2), 137-142. https:// doi.org/https:// doi.org/10.31004/obsesi.v5i1.598

Armstrong, T. (2003). Sekolah Para Juara (Menerapkan Multiple Intelegences di Dunia Pendidikan). Kaifa.

Beaty. (2013). Observasi Perkembangan Anak Usia Dini. Kencana.

Beceren, O. . (2010). Deteremining Multiple Intelligences Pre-school Children (4-6 age) in Learning Process. Procedia-Social Behavioral Sciences 2, 2473-2480.

Behjat, F. (2012). Interpersonal and Intrapersonal Intellligences: Do they Really Work in Foreign-Language Learning. Procedia-Social Behavioral Sciences 32, 351-355. 
Strategi Guru PAUD dalam Mengembangkan Kecerdasan Interpersonal Anak Usia Dini

DOI: 10.31004/obsesi.v5i2.1055

Borg, W. R., \& Gall, M. D. (2003). Educational Reseach : An Introduction. Longman, Inc.

Brown, P. C. (2010). Balancing The Readiness Equation In Early Childhood Education Reform. Journal of Early Childhood Research, 8, 133.

Hurlock, E. (2001). Psikologi Perkembangan Suatu Pendekatan Sepanjang Rentang Kehidupan. Erlangga.

Inten, D. . (2017). Peran Keluarga dalam Menanamkan Literasi Dini pada Anak Role of the FamilyToward Early Literacy of the Children. Golden Age: Jurnal Pendidikan Anak Usia Dini, 1(1), 23-32. https:// doi.org/10.29313/ga.v1i1.2689

Lazear, D. (1999). Multiple intelligence approaches to assessment: Solving the assessment conundrum. Hawker Brownlow Education.

Lwin, M. et. a. (2003). Cara Mengembangkan Berbagai Kecerdasan. PT Indeks Kelompok Gramedia.

Musfirah, T. (2004). Bermain sambil Belajar dan Mengasah Kecerdasan (Stimulasi Multiple Intelegences Anak Usia Taman Kanak-kanak). Direktorat Pembinaan Pendidikan Tenaga Kependidikan dan Ketenagaan Perguruan Tinggi Subdit PGTK dan PLB.

Muslihuddin, \& Agustin, M. (2017). Mengenali dan Mengembangkan Potensi Kecerdasan Majemuk Anak Usia TK/RA. Wafimedia Tama.

Nurihsan, J., \& Agustin, M. (2011). Dinamika Perkembangan Anak dan Remaja. Refika Aditama.

Pahrul, Y. (2019). Peningkatan Kecerdasan Interpersonal Melalui Kegiatan Menggambar pada Anak Usia Dini. Jurnal Obsesi: Jurnal Pendidikan Anak Usia Dini, 3(2), 461-469. https://doi.org/https://doi.org/10.31004/obsesi.v3i2.186

Pahrul, Yolanda, Hartati, S., \& Meilani, S. M. (2019). Peningkatan Kecerdasan Interpersonal melalui Kegiatan Menggambar pada Anak Usia Dini. Jurnal Obsesi : Jurnal Pendidikan Anak Usia Dini, 3(2), 461. https://doi.org/10.31004/obsesi.v3i2.186

Permatasari, A. N., Inten, D. N., \& Widiyanto, K. N. (2021). Jurnal Obsesi : Jurnal Pendidikan Anak Usia Dini Keintiman Komunikasi Keluarga saat Social Distancing Abstrak. 5(1), 346359. https:// doi.org/10.31004/obsesi.v5i1.577

Qowiyah, S. H. (2020). Analisis kecerdasan interpersonal anak kelompok b. 11(2).

Royani, M. (2016). Mengembangkan Kecerdasan Interpersonal Dan Kepercayaan Diri Siswa Melalui Efektivitas Model Pembelajaran Pbl. Math Didactic, 2(2), 106-115. https:// doi.org/10.33654/math.v2i2.35

Sahidun, N. (2018). Increasing Early Childhood Interpersonal Intelligence through Indigenous Games. Journal of Early Childhood Care E Education, 1(1), 13-17.

Sari, Y. (2018). Outbond as the Basic of Multiple Intelligences Learning Activity. Chatarsis, 7(3), 311-318.

Sary, E. (2018). Relationship of Parenting with Child Interpersonal Intelligence in Wonokerto Village, Lumajang Regency. Jurnal Obsesi : Jurnal Pendidikan Anak Usia Dini, 2(2), 137142. https:// doi.org/10.31004/obsesi.v2i2.93

Suhaimi, A. W., Marzuki, N. A., \& Mustaffa, C. S. (2014). The Relationship between Emotional Intelligence and Interpersonal Communication Skills in Disaster Management Context: A Proposed Framework. Procedia - Social and Behavioral Sciences, 155(October), 110-114. https://doi.org/10.1016/j.sbspro.2014.10.265

Syaodih, E. (1999). Peranan Bimbingan Guru, Pengasuhan Orang Tua, dan Interaksi Teman Sebaya terhadap Perkembangan Perilaku Sosial Anak Taman Kanak-kanak. IKIP Bandung.

Tatminingsih, S. (2019). Kemampuan Sosial Emosional Anak Usia Dini di Nusa Tenggara Barat. Jurnal Obsesi: Jurnal Pendidikan Anak Usia Dini, 3(2), 484-493. https://doi.org/https://doi.org/10.31004/obsesi.v3i2.170

Utami, A. D. (2010). Peningkatan Kecerdasan Intrapersonal dan Kecerdasan Interpersonal Melalui Pembelajaran Project Approach. Universitas Negeri Jakarta, 7(2), 56.

Wee, S. . et. a. (2013). Young Children's Role-Playing for Enhacing Personal Intelligences in Multiple Intelligences Theory. International Reseach in Early Chilhood Education, 4(1), 53. 